\title{
Analysis of the factors that affecting Intention to use Tourism Online Booking
}

\author{
Adele Mailangkay ${ }^{1}$, Eko Indrajit ${ }^{2}$, Raymond Kosala ${ }^{3}$, Acep Hidayat ${ }^{4}$ \\ ${ }^{1}$ Bina Nusantara University, Indonesia, adele.m@gmail.com \\ ${ }^{2,3,4}$ Bina Nusantara University, Indonesia
}

\begin{abstract}
Tourism has been closely connected with the advancement of Information and Communication Technology for over 30 years. In 2014, the travel industry is still the king in the e-commerce industry of Indonesia. But there are some things that hinder Indonesian people using e-commerce. Previous research has subjectively contributed to the design and marketing of the online tourism industry, but no one has done an evaluation directly through user perspective assessment. The absence of a theoretical reference model causes significant ambiguity regarding how to create e-travel sites and evaluates them in practice. In this study, it is proposed and validate an evaluation model of the use of e-commerce in tourism derived from previous research theories linked to the risk theory of the Davis's Technology Acceptance Model (TAM). The results obtained from this research indicate that the interest of users of travel booking applications online is influenced by several factors, namely: technology, environment, behavior, and e-lifestyle. The purpose of this research is to understand which factors influence the intention of using tourism booking applications online.
\end{abstract}

Key words: attitude, e-lifestyle, social influence, technology acceptance model, tourism online booking.

\section{INTRODUCTION}

The travel industry has been firmly connected with the headway of Information and Communication Technology for more than 30 years. The foundation of the Computer Reservation Systems in 1970, the Global Distribution Systems in the late 1980s and the Internet in the late 1990s has drastically changed operational and key practices in the travel industry. The travel industry at first centered around the utilization of mechanized frameworks (eg, CRS, GDS) to improve proficiency in inward data handling and oversee dissemination. Today, the relevant Internet and Information and Communications Technology are used across all operations, structural, strategic and marketing levels to facilitate global interaction between suppliers, intermediaries and consumers worldwide [1].
The e-tourism business is growing in line with the increasing speed of internet access and is supported by the use of a website which is an effective way to improve communication and engagement between customers and this business [2].

From the results of research conducted by [3] in the tourism industry it is found that research needs to be conducted to find out how ICT can recognize the needs of consumers in purchasing tourism services in general and hospitality products and services in particular. Tourists need information before they travel to help them plan and choose between tourism destination options, and determine how best to achieve their goals while travelling. In addition there is an increasing need for information during the trip as a result of the increasing trend of tourism.

Travelers need access to data any place and at whatever point they need to compose their outings. This implies the field of the travel industry is an ideal application field for web and portable processing. Cell phones which run Android and iOS offer new chances to grow continuous programming applications. Cell phones assume a significant job in the travel industry since voyagers for the most part convey cell phones that they get to more than their PCs. Therefore, there is an increasing trend toward mobile-based applications utilizing these operating systems [4].

Growth of Internet utilization globally continues to increase. According to the latest data from We Are Social, the number of active internet users around the world has now reached 3.17 billion. Until 2016, the number of Internet users in Indonesia reached 132,7 million [5]. The growth of internet users is also affecting the growth of social and mobile media users. According to the same report, active social media users have now reached 2.2 billion, while mobile users number around 3.7 billion. Interestingly, the most significant growth is shown by users accessing social media via mobile platforms. Users of this type grew by 23.3 percent in 2015 . Meanwhile, Facebook is still the most widely used social media with almost 1.5 billion active users [6].

In view of an overview directed by the Association of Internet Network Providers Indonesia [5] uncovered that the greater part of Indonesia's populace has now been associated with the web. The overview, directed all through 2016, found that 132.7 million Indonesians were associated with the web. The all out populace of Indonesia itself in 2016 is the same 
number of as 256.2 million individuals. Such wide access to internet opens up opportunities for e-commerce.

According to [7], in 2017 there are 10 types of e-commerce where the largest is the Online Retail $45.87 \%$, followed by Marketplace of $16.5 \%$, while Travel is in the order of $5.61 \%$. From this data, there are still many opportunities for e-commerce in the field of tourism.

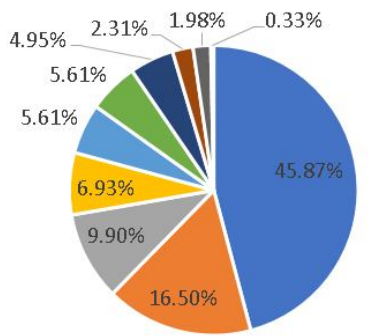

$$
\begin{array}{llll}
\text { - Online Retail } & \text { - Marketplace } & \text { - Infrastructure } & \text { " Payment Gateway } \\
\text { - Travel } & \text { - Logistik } & \text { - Classified Ads } & \text { - Bank } \\
\text { - Dailydeals } & \text { - Directory } &
\end{array}
$$

Figure 1: Percentage of E-commerce by Type (idEA, 2017)

'E-commerce' alludes to the utilization of the Internet to perform business exchanges. All the more officially, web based business is about financially potential exchanges among associations and people. Generally, this implies exchanges that happen over the Internet. Business exchanges include the trading of qualities (eg, cash) crosswise over hierarchical or singular limits as an end-result of items and administrations [8].

\section{LITERATURE REVIEW}

Based on existing studies, the quality of tourism websites can be identified based on at least six dimensions, namely:

\section{1) Ease of use}

There has been much research on the importance of ease of use as a determinant factor of website quality. Ease of use is a critical component of a customer's decision to adopt information technology [9]. Ease of use includes: ease of functionality; ease of access; consistency and effectiveness of navigation; the ability to search for and find the desired products and services. A website that has a high level of navigation difficulty and requires a long time to access, will most likely be abandoned by the user. So the dimension of ease of use refers to the degree to which the online customers who use the website feel free from effort.

\section{2) Content/Information}

High quality, up-to-date information, in sufficient quantities plays an important role in affecting customers' perception about the quality of a website. Too much or too little information on the website will cause the customer to ignore the page. Therefore the amount of information is important in attracting website visitors. Many researchers, among others, [10] stated that: comprehensive, unique, and precise information containing entertainment value and up-to-date information will increase the customer's intention to conduct transactions through a website. So the element of the substance is characterized as the degree to which the client thinks about the substance/data to be valuable, current and solid.

\section{3) Fulfillment}

Fulfillment refers to the delivery of products and services according to the level of service promised [11]. In fact, because service providers often have difficulty controlling delivery, quality, and timeliness; product and service compliance is a major obstacle to e-commerce. In the absence of a real possibility of real interaction between an online customer and a service provider, customers are often frustrated with the service they receive. Thus the fulfillment dimension is defined by the service, the monitoring of the order stages and the information provided about the online transactions.

\section{4) Responsiveness}

Opportune conveyance of reactions to solicitations or objections through email and request affirmation is a significant factor when clients assess a site [12]. To improve responsiveness, making a site based client service interface requires extraordinary regard for whether the interface is immediate, constantly accessible, and gives data about the administration cutoff time. Prompt service can be expected to increase perceived customer quality of a website. Thus the dimension of responsiveness can be defined as a desire or willingness to provide support to customers by providing prompt service within the context of a websites content/information.

\section{5) Security/Privacy}

Attention to security and privacy, is not only a critical aspect of online interaction but also as a major barrier to online purchases [13]. The measurement of website security and privacy systems is critical to increasing the level of customer trust and the desire to complete online transactions. In other words, a website should provide the ability to maintain the confidentiality of customer information in order to improve the perceived quality of the website. Therefore the security and privacy dimensions are defined as the degree to which customers believe that the website will protect them from harm, risk or doubt.

\section{6) Visual Appeal}

Graphic design and presentation of a website can be identified with the physical environment of a store and have a great influence on customers. In particular, the design and aesthetics of web pages can have an effect on the perceived 
attractiveness of an e-business [14]. The combination of color, type and font size; animation, sound effects; and clarity, and ease of ability to read a text make a website visually appealing and user-friendly. The creativity and uniqueness of the page layout can attract customers and encourage them to re-visit the site, while poor design and layout will hamper the return of customers. The main challenge of an e-business lies in optimizing the visual and aesthetic appeal of its site in such a way as to optimize the flow of processes and meet customer needs for the customer's online experience as well as the behavior.

Most behavioral theories agree and believe that the main and only predictor that can predict individual behavior is their interest to behave. In other words, behavioral intention is the predecessor of the actual behavior of individuals. Theories based on this opinion are the Theory of Reasoned Action [15] and the Theory of Planned Behavior [16]. Considering the research of [15] who formulated Theory of Reason Action (TRA), Davis then refined his concept model by proposing a Technology Acceptance Model (TAM).

The exploration that directed by [17] proposes that sights or inns not just need to have potential clients to visit their locales, they likewise require a site that can impact clients to in the long run book their living arrangement by means of the site, as opposed to arrange through different channels. There should be support for the potential impacts of website intuitiveness on view of convenience, ease of use, and at last web based requesting goals. This research can expand the framework by integrating it with potential moderators in relation to the cultural diversity of online web browsers, readiness and tech habits.

As indicated by [18], despite the fact that forerunners of customer goal to partake in the online travel network clarify countless its fluctuation, there are other significant components that have not been remembered for their exploration model, which gives a chance to additionally inquire about (eg distinguishing proof, saw conduct control, and emotional standards). [19] suggested conducting research on actual behavior to order tourism products online.

[20] said that web architecture had huge impact on the conduct of webpage utilization in Internet banking. Web composition significantly affected the utilization of Internet banking through intervention of execution hope. Related knowledge had noteworthy effect on exertion hope in the utilization of Internet banking. Related knowledge had critical impact on execution hope in the utilization of Internet banking. Related knowledge significantly affected web architecture in the utilization of Internet banking. This is important because it increase the performance of the bank.

Other research that conducted by [21] shows that perceived usefulness has a positive and significant effect on attitude variables using e-money. The results of this study stated that electronic money products are beneficial for potential consumers, thus forming a positive attitude towards the use of electronic money.

\section{METHODS}

In this study, the evaluation model of e-commerce use in tourism, derived from the theoretical foundations of previous research related to perceived risk theory and technology acceptance model is examined and validated. Specifically, this study will examine the impact of factors affecting consumer behavior in seeking information and transactions through tourism ICT applications, primarily online reservation, namely: technology readiness; social influence; e-lifestyle; perceived ease of use; and perceived usefulness, which is felt to be related to changes in attitude and desire to make online reservations in planning the tour.

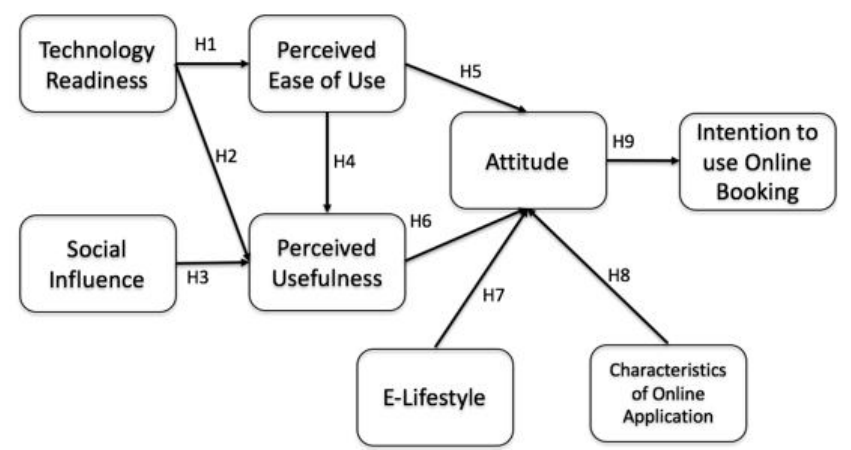

Figure 2: Research Model

Descriptive research aims to obtain a picture or characteristics of potential investors who want to use mobile online booking application. While research verification aims to determine the relationship between variables through a hypothesis testing based on data in the field.

This research is also verificative, which is a method that aims to test mathematically allegations about the relationship between variables of the problem under investigation in the hypothesis. Or in other words, this research will test: the influence of technology readiness on perceived ease of use; the effect of technology readiness on perceived usefulness; the influence of social influence on perceived usefulness; perceived ease of use on perceived usefulness; the influence of perceived ease of use on attitude; the influence of perceived usefulness toward attitude; influence of e-lifestyle on attitude; influence of application online character on attitude; and the influence of attitude on intention to use online booking application.

In accordance with the research problems described in chapter one, the research method used is a survey with a causal design. Survey methods are usually used to describe existing phenomena, but can also be used to compare the conditions studied with certain predefined criteria. Survey methods can also be used to assess the effectiveness of a program, as well as to investigate the influence or to test the hypothesis. The survey method, among others, depends on (1) the number of persons sampled; (2) the degree to which the 
sample is representative, meaning to represent the group under investigation; (3) The degree of confidence in the information obtained from the sample. Each method and research design has advantages and disadvantages so that the choice of method depends on the type and nature of the research. Survey method has advantages such as: (1) in the survey usually involves a large number of people to achieve generalizations or conclusions that are general character that can be accounted for. It is necessary to ensure that the sample actually represents the entire group under investigation; (2) in the survey can be used various data collection techniques such as questionnaires, interviews, and observations according to the choice of the researcher; (3) in the survey often appear problems that were previously unknown or suspected, so as well as exploratory; (4) by survey research may justify or reject certain theories; (5) the cost of the survey is relatively cheap in terms of the large number of people who provide information. Particularly when using questionnaires that can be sent over the internet, at low cost. When using interviews with contacts, with samples, it certainly costs much more [22].

The type of data used is quantitative data using an ordinal scale in the form of a Likert scale of 1-5. The sources of data used are primary data that is taken directly from the object of research, which comes from the answer to the questionnaire given directly to the respondent. The use of ordinal scale in this study aims to distinguish between categories in one variable with the assumption that there is a sequence or scale level. More ordinal numbers indicate rank. Ordinal scale is a measurement scale that not only states the category, but also states the rank of the construct being measured.

The reason the researcher uses a 5-point Likert scale is that it can give the respondent a considerable choice and increase the differentiation points, but does not bias the judgment and is not too broad. The categorization of the 1-5 scale is very clear and measurable. The third reason is the $1-5$ scale is very easy to interpret by interviewees. The fourth reason is that the scale of $1-5$ has been very often used in research, so that the sources will be familiar enough to fill in the questionnaire.

\section{RESULTS AND DISCUSSIONS}

The survey obtained the following results: the monthly income of respondents was dominated by respondents with an income of Rp 2.600.000, and up, as much as $49 \%$ of 200 respondents; $43 \%$ or 86 respondents have employment as employees; $37 \%$ or 74 respondents are in the age group 35-44 years ; how to find information and transactions related to tourism was dominated by respondents who do online booking use tourism applications as much as $76.5 \%$; the tools used by respondents to transact tours online is dominated by Smartphone / Tablet $49 \%$ and Laptop / Notebook as much as $36.5 \%$; the reason of the respondent to travel for recreation as much as $50.5 \%$ and job / service reasons as much as $43.5 \%$; in terms of online ordering respondents generally use the website for shopping, accommodation, transportation, tourist and culinary purposes equally between $16 \%$ to $18.5 \%$; while the expectation of respondents in the main online travel transactions is delivery on demand and on time by $20.5 \%$ and then followed by security aspects of $20 \%$ and ease of transactions at $17.5 \%$.

Table 1: Discrimination Validity Result

\begin{tabular}{lcccccccc}
\hline & AT & EL & IOU & KAO & PEU & PU & SI & TR \\
\hline Attitude & 0.835 & & & & & & & \\
E-Lifestyle & 0.789 & 0.878 & & & & & & \\
Intention of Use & 0.826 & 0.658 & 0.889 & & & & & \\
Characteristics of & 0.858 & 0.791 & 0.817 & 0.888 & & & & \\
Online Application & & & & & & & & \\
Perceived Ease of Use & 0.833 & 0.710 & 0.713 & 0.765 & 0.898 & & & \\
Perceived Usefulness & 0.849 & 0.761 & 0.720 & 0.814 & 0.835 & 0.912 & & \\
Social Influence & 0.790 & 0.691 & 0.753 & 0.760 & 0.742 & 0.821 & 0.788 & \\
Technology Readiness & 0.729 & 0.658 & 0.681 & 0.737 & 0.751 & 0.735 & 0.657 & 0.939 \\
\hline
\end{tabular}

From the results of data processing using Smartpls program, AVE roots on diagonal versus correlation values between constructs as shown in Table 2, apparently have an AVE root value higher or greater than 0.5 , which means that the construct has high discriminant validity.

Table 2: Reliability Test Result

\begin{tabular}{lllll}
\hline & $\begin{array}{c}\text { Composite } \\
\text { Reliability }\end{array}$ & $\begin{array}{c}\text { Cronbach's } \\
\text { Alpha }\end{array}$ & AVE & Conclusion \\
\hline Attitude & 0.901 & 0.853 & 0.697 & Reliable \\
E-Lifestyle & 0.931 & 0.901 & 0.771 & Reliable \\
$\begin{array}{l}\text { Intention to use Online } \\
\text { Mobile Tourism Booking }\end{array}$ & 0.938 & 0.912 & 0.791 & Reliable \\
$\begin{array}{l}\text { Applications } \\
\text { Characteristis of Online }\end{array}$ & 0.949 & 0.932 & 0.788 & Reliable \\
$\begin{array}{l}\text { Applications } \\
\text { Perceived Ease of Use }\end{array}$ & 0.954 & 0.939 & 0.806 & Reliable \\
Perceived Usefulness & 0.961 & 0.949 & 0.832 & Reliable \\
Social Influence & 0.891 & 0.846 & 0.62 & Reliable \\
Technology Readiness & 0.937 & 0.865 & 0.881 & Reliable \\
\hline
\end{tabular}

Loading factor for each indicator of each variable there is no value below 0.70 . Composite reliability of each construct is very good above 0.80 . The average variance extracted (AVE) validity value for each construct value is above 0.50 and with Cronbach's Alpha value above 0.6. This indicates that the construct has a reliable value or satisfies the reliability test. High reliability shows that indicators have a high consistency in measuring their latent constructs.

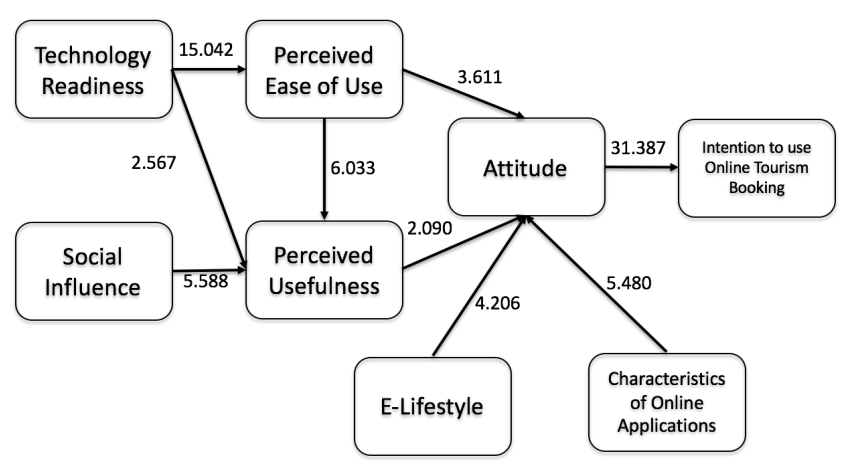

Figure 3. Research Model

Figure 3 shows how big the effects of each constancy are on the recommended model, making it easier to understand the 
role of the impact on the overall model. E-lifestyle and the characteristics of online applications are two factors that are added to this research model and have not been present in previous studies.

\section{CONCLUSION}

There is a significant and positive influence between Technology Readiness and perceived ease of use. Research respondents need the requisite technological readiness to feel at ease when using this technology. Therefore, the government needs to support by technology and information infrastructure. Online tourism booking application makers need to make the application easy to use, and these two variables will predict how the user perceives their experience using the technology. Of course, the latter variable (easy to use applications) is more easily controlled than the former (technological readiness). There is a significant and positive influence between Technology Readiness and Perceived Usefulness. Research respondents who have the requisite technological readiness will more likely feel that the technology is easy to use. Therefore, the online tourism booking application developers need to make the app feel useful. There is a significant and positive influence between Social Influence and Perceived Usefulness. Research respondents felt that the influence of the environment (friends and family) benefited him in using the online tourism booking application. There is a significant and positive influence between Perceived Ease of Use and Perceived Usefulness. Research respondents felt that the online tourism booking application was easy to use and thus beneficial to them. There is a significant and positive influence between Perceived Ease of Use and Attitude. Easier to use online tourism booking applications affected respondents' behavior. There is a significant and positive influence between Perceived Usefulness and Attitude. Research respondents felt that the use of an online tourism booking application was beneficial to them, thus affecting the behavior of respondents in using the application. There is a significant and positive influence between E-lifestyle and Attitude. Research respondents felt that using the internet was a lifestyle and this had an effect to use of online tourism booking applications. There is a significant and positive influence between Characteristics of Online Applications and Attitude. Research respondents felt that the characteristics of online tourism booking applications had an effect on their behavior. There is a significant and positive influence between Attitude and the Intention to use Online Tourism Booking Applications. Research respondents felt that his behavior had an effect on the intention of using an online tourism booking application.

Suggestions which can be drawn from this research are that the government should support tourism by providing and empowering information technology infrastructure, especially internet that is evenly distributed throughout the region in Indonesia. Online tourism booking application developers should consider factors related to lifestyle in today's society and the characteristics of online applications in demand by those who wish to make online tourism reservations when making applications.

\section{REFERENCES}

[1] D. Buhalis and R. Law, "Progress in information technology and tourism management: 20 years on and 10 years after the Internet-The state of eTourism research," Tour. Manag., vol. 29, no. 4, pp. 609-623, 2008. https://doi.org/10.1016/j.tourman.2008.01.005

[2] C. Suteja, S. Santoso, G. Wang, and E. Overview, "International Journal of Advanced Trends in Computer Science and Engineering Development Stages and Online Marketing Analysis of ' Open Trip ' E-Tourism Websites in Indonesia," vol. 8, no. 5, 2020. https://doi.org/10.30534/ijatcse/2019/23852019

[3] R. Law, D. Buhalis, and C. Cobanoglu, "Progress on information and communication technologies in hospitality and tourism," Int. J. Contemp. Hosp. Manag., vol. 26, no. 5, pp. 727-750, 2014. https://doi.org/10.1108/IJCHM-08-2013-0367

[4] V. Singh, A. Bali, A. Adhikthikar, and R. Chandra, "Web and mobile based tourist travel guide system for Fiji's tourism industry," Asia-Pacific World Congr. Comput. Sci. Eng. APWC CSE 2014, 2014.

[5] APJII, "Penetrasi Pengguna Internet Indonesia," 2017. [Online]. Available: https://www.apjii.or.id/ . [Accessed: 12-Nov-2016].

[6] Techinasia, "Statistik Pengguna Internet dan Media Sosial Terbaru 2015," 2015. [Online]. Available: https://id.techinasia.com/talk/statistik-pengguna-interne t-dan-media-sosial-terbaru-2015 . [Accessed: 12-May-2016].

[7] IdEA, 2017, [Online]. Available: https://www.idea.or.id/direktori-member [Accessed: 12-May-2016]

[8] J. P. Laudon, K.C. \& Laudon, Management Information Systems: Managing The Digital Firm, 14th ed. Pearson, 2016.

[9] F. D. Davis, "Perceived Usefulness, Perceived Ease of Use, and User Acceptance of," Inf. Technol. MIS Q., vol. 13, no. 3, pp. 319-340., 1989. https://doi.org/10.2307/249008

[10] O. Sigala, M., \& Sakellaridis, "The impact of users' cultural characteristics on e-service quality: Implications for globalizing tourism and hospitality Web sites," $A$. Frew (Ed.), Inf. Commun. Technol. Tour., pp. 106-117, 2004.

[11] J. M. Field, G. R. Heim, and K. K. Sinha, "Managing Quality in the E-Service System: Development and Application of a Process Model," Prod. Oper. Manag., vol. 13, no. 4, pp. 291-306, 2009.

[12]C. Long, M., \& McMellon, "Exploring the determinants of retail service quality on the Internet," J. Serv. Mark., vol. 18, no. 1, pp. 78-90, 2004. https://doi.org/10.1108/08876040410520726 
[13] S. J. Shchiglik, C., \& Barnes, "Evaluating Web site quality in the airline industry," J. Comput. Inf. Syst., vol. 44, no. 3, pp. 17-25, 2004.

[14] J. Schaik, P.V., \& Ling, "Five psychometric scales for online measurement of the quality of human-computer interaction in Web sites," Int. J. Hum. Comput. Interact., vol. 18, no. 3, pp. 309-322, 2005.

[15]I. Fishbein M \& Jazen, Belief, Attitude, Intention and Behavior: An Introduction to Theory and Research. Reading, MA: Addison-Wesley, 1975.

[16] I. Ajzen, "The social psychology of decision making. In E. T. Higgins \& A. W. Kruglanski (Eds.), Social psychology: Handbook of basic principles (pp. 297-325). New York: Guilford Press.," no. January 1996, pp. 297-325, 1996.

[17]D. Abdullah, K. Jayaraman, D. N. Shariff, K. A. Bahari, and N. M. Nor, "The Effects of Perceived Interactivity, Perceived Ease of Use and Perceived Usefulness on Online Hotel Booking Intention: A Conceptual Framework," Int. Acad. Res. J. Soc. Sci., vol. 3, no. 1, pp. 16-23, 2016.

[18] G. Agag and A. A. El-Masry, "Understanding consumer intention to participate in online travel community and effects on consumer intention to purchase travel online and WOM: An integration of innovation diffusion theory and TAM with trust," Comput. Human Behav., vol. 60, pp. 97-111, 2016.

https://doi.org/10.1016/j.chb.2016.02.038

[19] Y. Park, S. \& Huang, "Motivators and inhibitors in booking a hotel via smartphones," Int. J. Contemp. Hosp. Manag., vol. 29, no. 1, pp. 161-178, 2017.

[20] R. R. W. Giri and K. M. Wellang, "Impact of website design, trust, and internet skill on the behaviour use of site internet banking in Bandung Raya: A modification of the utaut model," Pertanika J. Soc. Sci. Humanit., vol. 24, no. July, pp. 35-50, 2016.

[21]P. G. D. Sumerta, I Komang, Widyagoca, I Gusti Putu Agung, Adiandari, Ade Maharini, Herlambang, "Analysis of Technology Acceptance Model (TAM) to Use E-Money in Bali Province," vol. 8, no. 1, pp. 206-211, 2019. https://doi.org/10.30534/ijatcse/2019/3881.52019

[22]S. Nasution, Metode Research (Penelitian Ilmiah). Jakarta: Bumi Aksara, 2007. 